\title{
TEN-YEAR RESULTS OF OPERATIONS FOR RHEUMATOID CERVICAL SPINE DISORDERS
}

\author{
SEPPO SANTAVIRTA, YRJÖ T. KONTTINEN, ERKKI LAASONEN, VISA HONKANEN, \\ ILKKA ANTTI-POIKA, MARKKU KAUPPI
}

From University Central Hospital, Helsinki

\begin{abstract}
The outcome of operations performed on 38 patients for rheumatoid disorders of the cervical spine were analysed 10 or more years later. The mean age of the patients at the time of operation was 56 years (35 to 77); 32 had seropositive disease. The mean duration of the disease was 17 years (four to 36 ).

Twenty-seven patients had painful anterior atlanto-axial subluxation (AAS), nine had subaxial subluxation alone and two had severe cranial subluxation of the odontoid, one also with subaxial subluxation.

One patient died from postoperative staphylococcal septicaemia and another 18 died during the followup period. Patients with coincident cardiac or other diseases, and those with cranial subluxation of the odontoid of more than $3 \mathrm{~mm}$ had an increased mortality. Neither the patients' age nor the magnitude of AAS correlated with mortality.

Of the 37 patients with occipitocervical pain, 30 were relieved and all the six patients with tetraparesis were improved.

Of the 24 Gallie fusions only 12 were solidly united; patients with long-term cortisone treatment were more likely to develop pseudarthrosis. There was no correlation between clinical outcome and radiological result.
\end{abstract}

Four patients had further operations to treat subluxation which developed below the fused segments.

In patients with severe rheumatoid arthritis, the cervical spine commonly becomes unstable as a result of inflammation in the vertebral synovial joints (Konttinen et al 1987a, b; Santavirta et al 1987a). Subluxations are common and have been described in seropositive, seronegative and juvenile rheumatoid arthritis, as well as seronegative spondylo-arthropathy (Kankaanpää and

S. Santavirta, Orthopaedic Surgeon

Orthopaedic Hospital of the Invalid Foundation, Tenholantie 10, SF-00280 Helsinki, Finland.

Y. T. Konttinen, Visiting Professor

Hospital of Joint Diseases Orthopaedic Institute, 301 East 17th Street, New York 10003, New York, USA.

E. Laasonen, Head

Radiology Department, Department of Orthopaedics and Traumatology, University Central Hospital, SF-00260 Helsinki, Finland.

V. Honkanen, Research Fellow

Division of Rheumatology, Fourth Department of Medicine, University Central Hospital, SF-00170 Helsinki, Finland.

I. Antti-Poika, Senior Investigator

Department of Central Administration, University Central Hospital, SF-00290 Helsinki, Finland.

M. Kauppi, Research Fellow

Rheumatism Foundation Hospital, SF-18120 Heinola, Finland.

Correspondence should be sent to Dr S. Santavirta at W. Aaltosentie 9, SF-00570 Helsinki, Finland.

(C) 1991 British Editorial Society of Bone and Joint Surgery

0301-620X/91/1048 \$2.00

J Bone Joint Surg [Br] 1991 ; 73-B:116-20.
Santavirta 1985; Santavirta et al 1987b, c). The incidence of subluxation varies with the severity and duration of the disease. Radiographic subluxation is seen in more than $80 \%$ of patients who have had severe polyarticular disease for more than 20 years (Conlon, Isdale and Rose 1966; Dirheimer and Babin 1974; Kankaanpää and Santavirta 1985; Santavirta et al 1987c).

Since 1974, we have collected data on patients treated operatively and conservatively for cervical spine disorders caused by rheumatoid arthritis and other chronic inflammatory joint diseases (Santavirta, Sandelin and Slätis 1985; Santavirta et al 1988b; Slätis et al 1989; Konttinen et al 1989). Most patients with rheumatoid cervical spine lesions can and should be treated conservatively (Althoff and Goldie 1980), though several authors have advocated operative treatment for selected patients (Ranawat et al 1979; Crockard et al 1985; Brattström 1986; Zoma et al 1987; Santavirta et al 1988b). The main reason for operative treatment in our series, and in those published by others was painful anterior atlanto-axial subluxation (Ranawat et al 1979; Santavirta et al 1986; Konttinen et al 1990).

To date, all the studies on operatively treated patients have been based on relatively short follow-up, usually less than five years. The object of the present work was to establish the long-term outcome in patients whose cervical spine lesions were treated operatively. 
Table I. Details of 38 patients who were operated on for rheumatoid lesions of the cervical spine and whose outcome was evaluated more than 10 years later

\begin{tabular}{|c|c|c|c|c|c|c|c|c|}
\hline Case & Sex & $\begin{array}{c}\text { Age } \\
\text { (yr) }\end{array}$ & $\begin{array}{l}\text { Duration of } \\
\text { disease (yr) }\end{array}$ & $\begin{array}{l}\text { Duration of } \\
\text { cervical } \\
\text { symptoms (yr) }\end{array}$ & $\begin{array}{l}\text { Atlanto-axial } \\
\text { subluxation } \\
(\mathrm{mm})\end{array}$ & $\begin{array}{l}\text { Site of } \\
\text { dens }(\mathrm{mm}) \S\end{array}$ & $\begin{array}{l}\text { Subaxial } \\
\text { subluxation }\end{array}$ & $\begin{array}{l}\text { Main } \\
\text { complaint } \mid\end{array}$ \\
\hline 1 & F & 63 & 36 & 1 & 5 & -3 & - & 0 \\
\hline 2 & $\mathrm{~F}$ & 49 & 15 & 4.5 & 11 & -4 & - & O,D \\
\hline 3 & $\mathrm{~F}$ & 41 & 17 & 3 & - & -2 & C3-4 & O,D \\
\hline 4 & M & 63 & 34 & 25 & - & -2 & C3-4 & $\mathrm{O}, \mathrm{D}$ \\
\hline 5 & M & 58 & 14 & 10 & 17 & -7 & - & $O, D$ \\
\hline 6 & $\mathrm{~F}$ & 43 & 23 & 4 & 2 & +10 & - & $O, D$ \\
\hline 7 & $F$ & 63 & $18^{*}$ & 6 & 13 & -3 & - & $\mathrm{O}, \mathrm{D}$ \\
\hline 8 & $\mathbf{F}$ & 57 & 15 & 4 & 10 & +16 & C3-4 & O,D \\
\hline 9 & $\mathbf{M}$ & 49 & 15 & 2 & 6 & -4 & - & $\mathrm{O}, \mathrm{T}$ \\
\hline 10 & $\mathrm{~F}$ & 41 & 12 & 4 & - & -1 & C3-4 & 0 \\
\hline 11 & $\mathrm{~F}$ & 51 & $9^{*}$ & 2 & 10 & -4 & - & 0 \\
\hline 12 & $\mathrm{~F}$ & 74 & 24 & 1 & 14 & +4 & - & O,D \\
\hline 13 & $\mathrm{~F}$ & 61 & 16 & 1 & 10 & -3 & - & $\mathrm{O}, \mathrm{D}, \mathrm{T}$ \\
\hline 14 & F & 64 & 21 & 4 & - & -5 & C6-7 & O,D \\
\hline 15 & $\mathrm{~F}$ & 77 & 20 & 1 & 18 & -6 & - & $O, D$ \\
\hline 16 & F & 55 & 33 & 13 & 11 & -7 & - & 0 \\
\hline 17 & $\mathbf{F}$ & 51 & 18 & 0.8 & - & +1 & C5-6 & O,D \\
\hline 18 & $\mathbf{M}$ & 58 & 14 & 7 & 12 & -5 & - & $\mathrm{O}, \mathrm{D}$ \\
\hline 19 & $\mathrm{~F}$ & 50 & 10 & 7 & 10 & -2 & - & $\mathrm{O}, \mathrm{D}, \mathrm{T}$ \\
\hline 20 & $\mathrm{~F}$ & 51 & 4 & 2 & 8 & -4 & - & 0 \\
\hline 21 & F & 44 & $31 \dagger$ & 6 & 9 & -5 & - & O,D \\
\hline 22 & F & 72 & $30^{*}$ & 8 & 7 & -5 & - & 0 \\
\hline 23 & $\mathrm{~F}$ & 43 & 27 & 7 & 11 & -2 & - & O \\
\hline 24 & F & 35 & $19 \pm$ & 0.5 & 13 & -7 & - & O,D \\
\hline 25 & $\mathbf{F}$ & 50 & 13 & 2.5 & 14 & -5 & C3-4 & 0 \\
\hline 26 & $\mathbf{M}$ & 64 & 13 & 1 & 12 & -7 & C4-5 & O,D \\
\hline 27 & $\mathrm{~F}$ & 53 & 16 & 2 & 12 & -2 & - & $\mathrm{O}, \mathrm{D}$ \\
\hline 28 & $\mathrm{~F}$ & 68 & 20 & 1 & 9 & +3 & - & $O, D$ \\
\hline 29 & $\mathrm{~F}$ & 74 & 12 & i & 11 & +1 & - & O,D \\
\hline 30 & $\mathbf{F}$ & 55 & 20 & 0.3 & 10 & +4 & - & $\mathrm{O}, \mathrm{D}, \mathrm{T}$ \\
\hline 31 & $\mathbf{M}$ & 57 & 10 & 8 & 8 & -2 & - & O \\
\hline 32 & $\mathrm{~F}$ & 66 & 21 & 0.7 & 11 & -4 & - & O,D \\
\hline 33 & $\mathbf{M}$ & 49 & 8 & 1 & 11 & -4 & - & O,D \\
\hline 34 & $\mathrm{~F}$ & 55 & 10 & 7 & 5 & -9 & C3-4 & $T$ \\
\hline 35 & $\mathbf{F}$ & 44 & 18 & 2.5 & 7 & +2 & - & O,D \\
\hline 36 & $\mathbf{M}$ & 52 & 7 & 1 & 9 & -4 & C6-7 & $T$ \\
\hline 37 & $F$ & 39 & 8 & 2 & 12 & +1 & - & O \\
\hline 38 & $\mathbf{M}$ & 50 & 4 & 1 & 17 & +3 & - & 0 \\
\hline
\end{tabular}

\section{PATIENTS AND METHODS}

From 1972 to 1978, we operated on 38 patients for rheumatoid disorders of the cervical spine at the University Central Hospital, Helsinki. Their pre-operative status is recorded in Table I. In 1989 we conducted a review, the results of which are shown in Table II. Those who had died were evaluated from their detailed records up to the time of death; and by their post-mortem records.

There were 30 women and eight men; their ages ranged from 35 to 77 years (average 56). Thirty-two had seropositive rheumatoid polyarthritis, three had the seronegative form of disease, two had juvenile rheumatoid arthritis, and one had ankylosing spondylitis. The mean duration of the disease at the time of operation was 17 years (range four to 36 ) and the duration of symptoms, in the cervical spine, ranged from two months to 12 years (average 6.4 years). All the patients except one had retired from work because of the rheumatoid disease; all except four lived at home; all except one had multiple joint erosions. Twenty-seven patients had previous joint operations and 21 had had more than four. Twenty-four patients had hand deformities, including ulnar deviation of the fingers and 'swan-neck' deformities. Twenty-five patients had significantly restricted neck movements and eight were totally stiff. All except one had had chronic, severe head or neck pain which was not controlled by analgesics or cervical braces. Pain had been present for an average 3.9 years (range five months to 25 years).

We found the following neurological defects: severe dizziness in 14 patients, dysphagia in two, numbness of the mouth and tongue in five, hyper-reflexia in 17, positive Babinski sign in four, tetraparesis in six, signs of tetraplegia in three, numbness of the hands in 29 , and positive Lhermitte sign (electric-shock sensation along the spine on flexing the neck, Santavirta et al (1987c)) in 17 patients. Only one patient had urinary incontinence and none had faecal incontinence. The main symptoms which led to operative treatment are listed in Table $I$.

Before operation, 19 patients could walk without aid, one was bedridden due to tetraplegia and the other 18 walked with crutches or other walking devices.

Using the neurological evaluation system of Ranawat et al (1979), 27 patients were rated in class I (no 
neurological deficit), five in class II (subjective weakness, hyper-reflexia, and dysaesthesia), two in class IIIa (objective weakness and long-tract signs, but still able to walk) and four in class IIIb (objective weakness and severe long-tract signs, or not able to walk). Eight patients had cardiac insufficiency and two had amyloidosis affecting the kidneys. Twenty-four patients had been on corticosteroid treatment for more than four years. Twenty-three patients had worn cervical collars for several months before operation.

Three main types of radiological subluxation were distinguished, all patients having one or more: 1 ) anterior atlanto-axial subluxation (Dirheimer and Babin 1977) exceeded $5 \mathrm{~mm}$ in flexion in 27 patients and was more than $10 \mathrm{~mm}$ in 22 (maximum $18 \mathrm{~mm}$ ); 2) severe cranial subluxation of the odontoid process (Santavirta et al 1988a; Slätis et al 1989) with the dens reaching 10 and $16 \mathrm{~mm}$ above the foramen magnum, was present in two patients; and 3) severe subaxial subluxation (RedlundJohnell 1984) in 10 patients.

Patients with cranial subluxation of the odontoid had had their rheumatoid disease longer than those with anterior atlanto-axial or subaxial subluxation. Two patients with subaxial subluxation had pre-operative skull traction for two weeks, which slightly reduced their signs of tetraplegia.

The patients with anterior atlanto-axial subluxation as the main defect were treated with Gallie (1939) C1-2 fusions in all but two cases. One patient with ankylosing spondylitis had cancellous bone grafting between the occiput and C2, without fixation (Newman and Sweetnam 1969) and one patient had laminectomy of the atlas and was fused with bone graft and acrylic cement (Brattström and Granholm 1976; Brattström 1986).

The two patients with severe cranial subluxation of the dens were treated with Newman-type fusions. After Gallie or Newman fusions skull traction was not used, but the patients wore rigid cervical braces for six weeks and a soft rubber collar for a further six weeks.

In eight patients with subaxial deformities, posterior fusion of the unstable segments was performed. In three, with severe and rapidly progressing signs of cord

Table II. Type of surgery and outcome in patients reviewed more than 10 years after the operation. Patients who died were followed up until death

\begin{tabular}{|c|c|c|c|c|c|c|}
\hline \multirow[b]{2}{*}{ Case } & \multirow[b]{2}{*}{ Fusiont } & \multirow[b]{2}{*}{ Laminectomy } & \multicolumn{4}{|c|}{ Neurological class* } \\
\hline & & & Pre-op & Follow-up & $\begin{array}{l}\text { Fusion } \\
\text { united } \ddagger\end{array}$ & $\begin{array}{l}\text { Death } \\
\text { (at post-op) }\end{array}$ \\
\hline 1 & Gallie & - & I & I & $\mathbf{P}$ & - \\
\hline 2 & Gallie & - & I & IIIIb & $\mathbf{P}$ & - \\
\hline 3 & $C 2-5$ & $\mathrm{C} 3$ & I & I & s & - \\
\hline 4 & C $3-5$ & $\mathrm{C} 3$ & IIIa & II & s & 9.0 \\
\hline 5 & Gallie & - & I & I & s & 5.5 \\
\hline 6 & Newman & - & I & I & s & - \\
\hline 7 & Gallie & - & I & I & $\overrightarrow{\mathbf{P}}$ & - \\
\hline 8 & $C 2-4$ & - & I & IIIb & S & 11.0 \\
\hline 9 & Gallie & - & I & I & s & - \\
\hline 10 & $C 2-5$ & C3-4 & IIIa & I & s & - \\
\hline 11 & Gallie & - & I & II & $\mathbf{P}$ & 1.3 \\
\hline 12 & Gallie & - & II & I & s & 3.8 \\
\hline 13 & Gallie & - & IIIb & II & s & 3.1 \\
\hline 14 & C6-Thl & - & I & I & s & - \\
\hline 15 & Gallie & - & I & I & s & 3.8 \\
\hline 16 & Gallie & - & I & I & s & - \\
\hline 17 & C4-7 & - & I & II & $\mathbf{F}$ & 1.6 \\
\hline 18 & Brattström & - & I & I & S & - \\
\hline 19 & Gallie & - & I & I & s & - \\
\hline 20 & Gallie & - & I & I & s & - \\
\hline 21 & Gallie & - & I & I & s & - \\
\hline 22 & Gallie & - & I & I & $\mathbf{P}$ & 1.2 \\
\hline 23 & Newman & - & I & I & S & - \\
\hline 24 & Newman & - & I & I & S & - \\
\hline 25 & $\mathrm{Cl}-6$ & - & I & I & s & 2.6 \\
\hline 26 & Gallie & - & I & I & F & 0.4 \\
\hline 27 & Gallie & - & I & I & s & - \\
\hline 28 & Gallie & - & I & I & $\mathbf{P}$ & 6.3 \\
\hline 29 & Gallie & - & I & I & $\mathbf{P}$ & 7.9 \\
\hline 30 & Brattström & $\mathrm{Cl}$ & IIIb & IIIb & S & 2.2 \\
\hline 31 & Gallie & - & I & I & $\mathrm{F}$ & - \\
\hline 32 & Gallie & - & I & I & $\dot{S}$ & 1.8 \\
\hline 33 & Gallie & - & II & I & P & 6.2 \\
\hline 34 & C2-5 & C3 & IIIb & II & S & 9.0 \\
\hline 35 & Gallie & - & I & I & $\mathrm{F}$ & - \\
\hline 36 & C6-7 & - & IIIb & IIIb & - & 0.2 \\
\hline 37 & Gallie & - & I & I & $\mathbf{F}$ & - \\
\hline 38 & Gallie & - & I & I & S & 1.7 \\
\hline
\end{tabular}

* I, no deficit; II, subjective weakness, hyper-reflexia; IIIa, objective weakness but able to walk; IIIb, not able to walk 
compression, laminectomy was carried out at one or two levels with removal of the sublaminar constricting pachymeningitis and posterior fusion. The patients who had laminectomies had skull traction for six weeks following operation.

\section{RESULTS}

Complications. Four patients had postoperative complications. One patient treated by subaxial fusion without laminectomy, and who had postoperative skull traction for six weeks, died eight weeks after operation from staphylococcal septicaemia and pneumonia. Another patient treated for subaxial subluxation and who had skull traction postoperatively, developed bronchopneumonia, which subsided with antibiotic medication. One patient who had Brattström-type fusion had postoperative wound infection, which subsided after local revision and antibiotic treatment. One patient had a wound infection at the bone graft donor site in the posterior iliac crest.

Deaths during the follow-up period. Nineteen patients died during the follow-up period. The average interval from operation to death was 4.2 years (range two months to 11 years) and the average age at death was 62 years (range 51 to 82). The cause of death was unrelated to the cervical spine disease or its operative treatment; except in the one instance already referred to. Four of the six patients who were classified as IIIa or IIIb at the time of the operation, died between two months and nine years after operation, three from cardiac infarcts and one from staphylococcal sepsis. Patients who had cardiac disease at the time of the operation were at greater risk of death during the follow-up ( $p<0.0005$, Mantel-Cox test). Also those with more than $3 \mathrm{~mm}$ cranial subluxation of the odontoid were more likely to die $(p<0.065$, MantelCox). The age of the patients at the time of operation did not correlate with mortality, nor did the magnitude of the atlanto-axial subluxation.

Clinical results. In 30 cases the pre-operative occipitocervical pain was relieved; in six the pain was considerably improved and in one it was unchanged (Table II). Of the original 29 patients with dysaesthesia of the hands, 21 were cured of this symptom. All those with the preoperative Lhermitte sign were relieved. All the patients with pre-operative tetraparesis were improved though one continued to have signs of mild tetraplegia.

The Gallie procedure relieved severe occipitocervical pain in 21 out of 23 cases in which it was used and cured dysaesthesia of the hands in all but six. The magnitude of AAS did not affect the outcome. The Newman and the Brattström procedures were all effective in relieving neck pain and dysaesthesia of the hands (Table II).

The four subaxial laminectomies combined with posterior fusions cured the severe neck pain in two patients, improving the neurological classification in one, cured the tetraplegia in one and cured the tetraparesis in another (Table II). The four patients who had subaxial fusions without laminectomy had good pain relief. In two cases the neurological condition gradually worsened and three eventually died. In one of these patients two further fusions were performed to treat new subluxations below the segments originally fused.

Radiographic results. Of the 24 Gallie fusions, 12 were solidly united, four had united with fibrous union and there were eight pseudarthroses. The magnitude of AAS did not affect the outcome. Patients who had more than four years cortisone treatment had more fibrous unions and pseudarthroses $(p<0.07)$. In only eight cases did the Gallie fusion unite in the position to which it was reduced during the operation. In five cases with pseudarthrosis, the atlanto-axial facet-joint arthrosis had progressed and the erosion of the dens had increased. Four patients had re-operations for new subluxations below the fused segments.

There was no correlation between clinical outcome and radiological results.

\section{DISCUSSION}

We report the results in patients with 10 or more years follow-up after surgery for rheumatoid lesions in the cervical spine. During those years we have improved and modified our routines of pre-operative evaluation, patient selection and choice of operative technique, but some lessons can only be learned from long-term results.

Anterior atlanto-axial subluxation was the most common deformity $(83 \%)$ in the patients we operated on. Although any synovial joint in the cervical spine may be involved, the earliest changes are usually seen at the occipitocervical junction. Atlanto-axial laxity can sometimes be detected after only a few years of inflammatory disease and in the absence of changes in the joint cartilage or subchondral bone (Konttinen et al 1989). The chronic and severe pain which is seen at the later stage is due to compression or tension of the C2 nerve root (Santavirta et al 1986, 1987a; Konttinen et al 1990). Even very severe anterior atlanto-axial subluxation seldom results in lifethreatening neurological complications. The Gallie fusion has proved to be a very effective means of treating this severe pain and postoperative complications are, in our experience, few. We do not use postoperative skull traction but allow early postoperative mobilisation in a cervical brace (Althoff and Goldie 1980). Most vertebrae did not fuse in the position to which they were reduced at the operation (Zoma et al 1987) and pseudarthroses were common. However, it seems that fibrous stabilisation is adequate to relieve the symptoms. Our series indicates that this improvement is long-lasting. We regard anterior atlanto-axial subluxation of more than $9 \mathrm{~mm}$ in patients who have either progressive neurological deficits or intolerable occipitocervical pain as indications for a Gallie fusion. 
Two patients in our series had a very serious cranial subluxation (Slätis et al 1989) of the dens, with the peg 10 and $16 \mathrm{~mm}$ above the foramen magnum level, and there were several others with impending cranial subluxation. This type of subluxation is a late development of anterior atlanto-axial subluxation and is caused by derangement and collapse of the lateral facet joint masses (Santavirta et al 1988a). The neurological complications of this condition are unpredictable. Cranial subluxation of the dens should be detected at an early stage before major neural deficits appear. In such cases, the Newman occipitocervical fusion effectively arrests the progress of the subluxation and may considerably alleviate the symptoms. If the posterior arch of the atlas has herniated into the foramen magnum, we advocate decompression of the posterior edge of the foramen.

Subaxial subluxations are usually late developments in the aggressive forms of rheumatoid disease. Subaxial compression of the neural elements can also be caused by the soft tissues, as in rheumatoid pachymeningitis, arachnoiditis, pannus formation, or extradural nodules (Bland 1974; Crockard et al 1985). Today, the preoperative evaluation of these subaxial subluxations should include magnetic resonance imaging, which best reveals the site and type of compression. Posterior fusion without laminectomy should only be used in those patients who have pain but have no clinical or radiological signs of cord compression. Posterior decompression with posterior fusion can improve even severe neurological deficits (Santavirta et al 1990). Anterior procedures often fail (Ranawat et al 1979) because of osteoporosis of the vertebral bodies and we have found that acrylic cement and metal rods are of little use as additional stabilisers in rheumatoid cervical spines (Zoma et al 1987). We stress the risk of new subluxations developing below the fused segments.

Half of our patients died during the follow-up period. However, we estimate that their average age at death was about the same as that of other patients with equally severe rheumatoid disease. That there was only one death during the early postoperative period may reflect the benefits of early mobilisation and careful pre-operative assessment by physicians and anaesthetists.

We regard the surgical treatment of rheumatoid disease of the neck as useful: it usually cured the pain and improved the neurological symptoms for many years. All patients with severe rheumatoid disease should be frequently examined for neck symptoms so that they can be treated before they develop irreparable lesions.

This study was financially supported by the Finnish Academy of Sciences and the Juselius Foundation.

No benefits in any form have been received or will be received from a commercial party related directly or indirectly to the subject of this article.

\section{REFERENCES}

Althoff B, Goldie IF. Cervical collars in rheumatoid atlanto-axial subluxation: a radiographic comparison. Ann Rheum Dis 1980; 39:485-9.

Bland JH. Rheumatoid arthritis of the cervical spine. $J$ Rheumatol $1974 ; 1: 319-42$

Brattström H. Die Halswirbelsäule bei Polyarthritis. Radiologie, Indikationen zur Operation und Ergebnisse. Orthopäde 1986; 15:291-6.

Brattström H, Granholm L. Atlanto-axial fusion in rheumatoid arthritis : a new method of fixation with wire and bone cement. Acta Orthop Scand 1976; $47: 619-28$

Conlon PW, Isdale IC, Rose BS. Rheumatoid arthritis of the cervical spine: an analysis of 333 cases. Am Rheum Dis 1966; 25:120-6.

Crockard HA, Essigman WK, Stevens JM, Pozo JL, Ransford AO, Kendall BE. Surgical treatment of cervical cord compression in rheumatoid arthritis. Ann Rheum Dis 1985; 44:809-16.

Dirheimer Y, Babin E. Upward atlantoaxial dislocation in rheumatoid arthritis. Neuroradiology 1974; 7:229-36.

Gallie WE. Fractures and dislocations of cervical spine. Am J Surg $1939 ; 46: 495-9$.

Kankaanpää U, Santavirta S. Cervical spine involvement in rheumatoid arthritis. Ann Chir Gynacol 1985; 74,(Supp) 198:117-21.

Konttinen YT, Santavirta S, Bergroth V, Sandelin J. Inflammatory involvement of cervical spine ligaments in patients with rheumatoid arthritis and atlantoaxial subluxation. $J$ Rheumatol 1987a 14:531-4.

Konttinen YT, Santavirta S, Slätis P, et al. Pathogenesis of the rheumatoid cervical spine. Scand J Rheumatol Supp 1987b; 67: 50-5.

Konttinen YT, Santavirta S, Kauppi M, et al. Atlantoaxial laxity in rheumatoid arthritis. Acta Orthop Scand 1989; 60:379-82.

Konttinen YT, Santavirta S, Grönblad M, et al. A retrospective clinical and neuroimmunohistochemical study of rheumatoid arthritic patients with atlanto-axial subluxation. Scand $J$ Rheumatology $1990 ; 19: 43-9$
Newman P, Sweetnam R. Occipito-cervical fusion. J Bone Joint Surg [Br] 1969; 51-B:423-31.

Ranawat CS, O'Leary P, Pellicci P, Tsairis P, Marchisello P, Dorr L. Cervical spine fusion in rheumatoid arthritis. $J$ Bone Joint Surg [Am] 1979; 61-A :1003-10.

Redlund-Johnell I. Subaxial caudal dislocation of the cervical spine in rheumatoid arthritis. Neuroradiology 1984; $26: 407-10$.

Santavirta S, Sandelin J, Slätis P. Posterior atlanto-axial subluxation in rheumatoid arthritis. Acta Orthop Scand 1985; $56: 298-301$.

Santavirta S, Konttinen YT, Lindqvist C, Sandelin J. Occipital headache in rheumatoid cervical facet joint arthritis. Lancet 1986; 2:695.

Santavirta S, Konttinen YT, Lindqvist C, Bergroth V, Sandelin J. Chronische Cephalalgie als Folge von rheumatischer Spondylarthritis der Halswirbelsäule. Zentralbl Chir 1987a; 112:440-6.

Santavirta S, Slätis P, Sandelin J, Lindqvist C, Konttinen YT. Atlantoaxial subluxation in patients with seronegative spondylarthritis. Rheumatol Int 1987b; 7:43-6.

Santavirta S, Kankaanpää U, Sandelin J, Laasonen E, Konttinen YT, Slätis P. Evaluation of patients with rheumatoid cervical spine. Scand J Rheumatol 1987c; 16:9-16.

Santavirta S, Hopfner-Hallikainen D, Paukku P, Sandelin J, Konttinen YT. Atlantoaxial facet joint arthritis in the rheumatoid cervical spine. J Rheumatol 1988a; 15:217-23.

Santavirta S, Slätis P, Kankaanpääa U, Sandelin J, Laasonen E. Treatment of the cervical spine in rheumatoid arthritis. $J$ Bone Joint Surg [Am] 1988b; 70-A :658-67.

Santavirta S, Konttinen YT, Sandelin J, Grönblad M, Antti-Poika I. Cervical spine subluxation in ankylosing spondylitis treated surgically. J Orthop Rheumatol 1990; 3:57-60.

Slätis P, Santavirta S, Sandelin J, Konttinen YT. Cranial subluxation of the odontoid process in rheumatoid arthritis. J Bone Joint Surg [Am] 1989; 71-A:189-95.

Zoma A, Sturrock RD, Fisher WD, Freeman PR, Hamblen DL. Surgical stabilisation of the rheumatoid cervical spine: indications and results. J Bone Joint Surg [Br] 1987; 69-B:8-12. 